\title{
Plasma Angiotensin II, Renin Activity and Serum Angioten- sin-Converting Enzyme Activity in Non-Insulin Dependent Diabetes Mellitus Patients with Diabetic Nephropathy
}

\author{
Wassef NICOLA, Gloria SIDHOM, ZaKareya El KHYAT, SaAdia IBRAHIM, Amani SALAH and \\ AhMed El SAYED
}

Basic Medical Sciences Department, National Research Center, Cairo, Egypt.

\begin{abstract}
The renin-angiotensin system (RAS) has been unequivocally implicated as a mediator of diabetic complications. The present study was designed to evaluate the RAS in non-insulin dependent diabetic patients with diabetic nephropathy. Plasma renin activity, plasma angiotensin II and serum angiotensin-converting enzyme (ACE) activity were measured in 45 non-insulin dependent diabetes mellitus (NIDDM) patients and 15 healthy non-diabetic controls. Diabetics were subdivided into 15 normoalbuminuric NIDDM subjects, 15 NIDDM patients with microalbuminuria and 15 diabetics with macroalbuminuria. Mean plasma renin activity for macroalbuminuric diabetics $(0.65 \pm 0.10 \mathrm{ng} / \mathrm{ml} / \mathrm{hr})$ was significantly reduced than the controls $(1.28 \pm 0.37 \mathrm{ng} / \mathrm{ml} / \mathrm{hr})(\mathrm{P}<0.001)$, the diabetic group with microalbuminuria $(1.08 \pm 0.48 \mathrm{ng} / \mathrm{ml} / \mathrm{hr})(\mathrm{P}<0.05)$ and normoalbuminuric patients $(1.56 \pm 0.82 \mathrm{ng} / \mathrm{ml} / \mathrm{hr})(\mathrm{P}<0.001)$. A significant negative correlation was obtained between serum creatinine and plasma renin activity $(\mathrm{r}=-0.842, \mathrm{p}<0.001)$ in macroalbuminuric NIDDM patients. Plasma angiotensin II was significantly decreased in non-complicated diabetics compared to healthy controls $(4.36 \pm 1.49 \mathrm{pg} / \mathrm{ml} \mathrm{vs}$ $14.87 \pm 3.48 \mathrm{pg} / \mathrm{ml}$ respectively, $\mathrm{p}<0.001)$. Non-insulin dependent diabetic patients with nephropathy had significantly higher plasma angiotensin II levels $(28.99 \pm 5.88 \mathrm{pg} / \mathrm{ml})$ than non-complicated diabetics $(\mathrm{p}<0.001)$. Serum ACE activity was increased in 53.3\% of NIDDM patients. All diabetic groups showed increased serum ACE activity (normoalbuminuric NIDDM $114.9 \pm 28.3 \mathrm{nmol} / \mathrm{min} / \mathrm{ml}$, microalbuminuric NIDDM $127.9 \pm 31.2 \mathrm{nmol} / \mathrm{min} / \mathrm{ml} \mathrm{and}$ macroalbuminuric NIDDM $127.0 \pm 29.3 \mathrm{nmol} / \mathrm{min} / \mathrm{ml})$ when compared to the normal control group $(76.3 \pm 16.5$ $\mathrm{nmol} / \mathrm{min} / \mathrm{ml})(\mathrm{p}<0.001)$. No significant difference in serum ACE activity was obtained between normoalbuminuric and nephropathic diabetics or between diabetics with and without retinopathy. No significant correlation was obtained between serum ACE activity and blood pressure, blood glucose level and duration of diabetes. Thus plasma renin activity is decreased in diabetic nephropathy and negatively correlates with serum creatinine. Plasma angiotensin II is decreased in normoalbuminuric diabetics and elevated in diabetic nephropathy. Serum ACE activity is raised in NIDDM patients with no relation to albumin excretion rate. The role of increased ACE activity in NIDDM remains to be established.
\end{abstract}

Key Words: Angiotensin II, Renin, Angiotensin-converting enzyme, Non-insulin dependent diabetes mellitus, Diabetic nephropathy.

(Endocrine Journal 48: 25-31, 2001)

Nephropathy is one of the most important causes of end-stage renal failure and is a strong predictor of mortality in individuals with diabetes mellitus [1].

\section{Received: June 23, 2000}

Accepted: October 4, 2000

Correspondence to: Gloria SIDHOM, M.D., Ph.D., P.O. Box

5216, Heliopolis West, 11771, Cairo, Egypt.
Classically, the renin-angiotensin system (RAS) in diabetes was thought to be suppressed, and relatively unimportant in the regulation of hemodynamics and the development of complications. However, recent developments have challenged this notion, and strongly implicated the RAS as a mediator of diabetic nephropathy [2]. Studies of pharmacological interruption of the RAS with angiotensin-converting en- 
zyme (ACE) inhibition have unequivocally implicated this hormonal system in the progression of diabetic nephropathy, both experimentally and clinically [3].

The present study was designed to evaluate the RAS with specific focus on serum ACE in non-insulin dependent diabetic patients with different stages of diabetic nephropathy.

\section{Materials and Methods}

\section{Study Population}

The study was conducted on 60 Egyptian subjects. Their relative demographic and clinical data were recorded. Forty-five of these subjects were NIDDM patients attending the Ain Shams University Hospital Diabetes Clinic in Cairo, Egypt. Diabetes was diagnosed according to WHO criteria (fasting glucose level $\geq 7.8 \mathrm{mmol} / 1$ and/or 2 -h glucose level $\geq 11.1$ mmol/l [4]). To provide a control group, 15 healthy nondiabetic subjects of matched age, sex and socioeconomic level were carefully chosen from the hospital staff members. The diabetics were subdivided into 3 groups according to the urinary albumin excretion rate, which was taken as the mean of two 24-h urine collections performed on consecutive days and determined by radioimmunoassay. Fifteen non-insulin dependent diabetics were normoalbuminurics defined by albumin excretion $<20 \mathrm{mg} / 24 \mathrm{~h}$. Thirty diabetic patients with nephropathy were classed as: 15 microalbuminurics with urinary albumin excretion in the range of $20-250 \mathrm{mg} / 24 \mathrm{~h}$ and 15 diabetics with macroalbuminuria with albumin excretion $>250 \mathrm{mg} / 24 \mathrm{~h}$.

All diabetic patients were further subjected to other diabetes complications examinations that included a complete ophthalmologic examination using slitlamps with three mirror glasses and assessment of retinopathy by retinal angiography. Neuropathy evidenced by neurological examination according to the Diabetes Control and Complications Trial criteria [5] was also determined. A cardiovascular screen included an electrocardiogram at rest, a treadmill test, and coronary angiography when indicated. Of the 45 diabetic subjects, none showed evidence of ischemic heart disease. The 15 normoalbuminuric diabetics were not complicated by other diabetic microvascular complications. Seven patients in the microalbuminuric group as well as 10 of the diabetics with macroalbuminuria had background retinopathy. Concomitant neuropathy was diagnosed in 11 out of 15 patients in each of both groups with diabetic nephropathy. The study was approved by the Review Board of the Ministry of Health in Cairo. None of the patients or control subjects was affected by conditions or medications known to influence the RAS. All subjects were instructed to adhere to their usual diet and restrict excess salt intake for at least 3 days prior to the study. Patients who were receiving ACE inhibitors or calcium antagonists were excluded. The doses of oral hypoglycemic drugs and insulin as well as the standard dietary carbohydrate recommendations were not altered. In addition, pregnant women and subjects with clinical or laboratory evidence of other kidney or urinary tract disease or infection were not eligible for this study. Informed consent was obtained from all subjects included in this study.

\section{Analytical Methods}

For each subject described in this report, blood specimens were drawn by venipuncture between $0800 \mathrm{~h}$ and $1000 \mathrm{~h}$ (to avoid the circadian change in the RAS) after a 12- to 14-h fast with the subjects lying in supine position for at least one hour prior to sampling. A portion of the blood was collected into pre-chilled lavender top vacutainers (containing EDTA) and plasma was immediately separated using a cooling centrifuge and stored at $-20^{\circ} \mathrm{C}$ for the subsequent determinations of angiotensin II and plasma renin activity. Serum extracted from clotted blood after centrifugation was used for the immediate determination of fasting glucose, urea, creatinine and serum electrolytes $\left(\mathrm{Na}^{+}\right.$and $\left.\mathrm{K}^{+}\right)$using the Beckman Synchron Autoanalyser. Serum for angiotensin converting enzyme activity was collected and frozen at $-20^{\circ} \mathrm{C}$ till the assay time.

Plasma renin activity was determined by competitive binding radioimmunoassay using the Gamma Coat [125I] Plasma Renin Activity RIA kit from Incstar Corporation (Incstar Science, Technology and Research, Stillwater, MN). The intra- and interrun coefficients of variation of this assay were 4.6 and $7.6 \%$, respectively. A double antibody radioimmunoassay (using monoclonal rabbit antibodies 
directed against angiotensin II) was used for the quantitative determination of immunoreactive angiotensin II in extracted EDTA plasma from Bühlmann Laboratories AG (Allschwill, Switzerland). The intra- and interassay coefficients of variation of this assay were 7.1 and $9.0 \%$, respectively. Serum ACE was assayed kinetically by direct quantitation with the Bühlmann ACE kinetic test kit (Bühlmann Labs AG) using the DU 700 Beckman spectrophotometer. Inter- and intraassay $\mathrm{CV}$ of 4.1 and $6.5 \%$ were respectively obtained for assay precision.

\section{Statistical Analysis}

Results were expressed as mean \pm SD. Statistical differences between groups were analyzed for significance using Student's t-test. In addition, linear regression analysis was applied for the correlation studies. Statistical significance was defined as $p<$ 0.05 .

\section{Results}

Clinical and routine laboratory data of the study subjects are shown in Table 1. Age and sex were statistically matched (no significant difference, $p>0.05$ ) in all studied groups. Only 4 of the NIDDM patients were hypertensive with systolic blood pressure greater than $140 \mathrm{mmHg}$ and/or diastolic blood pressure greater than $90 \mathrm{mmHg}$. Insulin therapy was administered to 7 of the 45 diabetics. Duration of diabetes in the normoalbuminuric, microalbuminuric and macroalbuminuric NIDDM patients was $4.3 \pm 1.6,6.8 \pm 4.4$ and $10.5 \pm 2.6$ years, respectively. The normoalbuminuric diabetic group showed no evidence of diabetic complications in the form of peripheral neuropathy, background retinopathy and nephropathy. A normal fundus was found in 8 out of the 15 microalbuminuric diabetics while only 5 of the diabetics with macroalbuminuria showed a normal fundus. Peripheral neuropathy was diagnosed in 22 of the nephropathic patients in this study.

Serum creatinine and urea were found to be increased in the NIDDM patients with macroalbuminuria. All diabetics showed elevated fasting blood glucose levels at sampling time. Specific laboratory data for the renin-angiotensin system are shown in Table 2. Mean plasma renin activity for the control group was $1.28 \pm 0.37 \mathrm{ng} / \mathrm{ml} / \mathrm{hr}$ while those of the normoalbuminuric and microalbuminuric NIDDM patients were $1.56 \pm 0.82$ and 1.08 $\pm 0.48 \mathrm{ng} / \mathrm{ml} / \mathrm{hr}$, respectively.

No statistical significance was noted between the latter two groups and the controls. Mean plasma renin activity for macroalbuminuric diabetics $(0.65$ $\pm 0.10 \mathrm{ng} / \mathrm{ml} / \mathrm{hr}$ ), however, was significantly reduced than the normal controls $(\mathrm{p}<0.001)$. In addition, a significant decrease was also noted in macroalbuminuric diabetics when compared to microalbuminuric NIDDM patients $(p<0.05)$ and those without proteinuria $(p<0.001)$. Diabetics without complications $(n=15)$ showed significantly higher renin activity $(1.56 \pm 0.82 \mathrm{ng} / \mathrm{ml} / \mathrm{hr})$ than those with nephropathy $(\mathrm{n}=30$; mean $0.87 \pm 0.41 \mathrm{ng} / \mathrm{ml} / \mathrm{hr} ; \mathrm{p}<0.01)$ (Table 3).

A significant negative correlation was obtained between serum creatinine and plasma renin activity $(\mathrm{r}=-0.842, \mathrm{p}<0.001)$ in macroalbuminuric NIDDM patients (Fig. 1).

Plasma angiotensin II was significantly decreased in non-complicated diabetics compared to values in healthy volunteers $(\mathrm{p}<0.001)$ (Table 2$)$. On the other hand, a significant increase in plasma angiotensin II levels was noted in microalbuminuric NIDDM patients when compared to both normal controls and normoalbuminuric diabetics $(\mathrm{p}<0.001)$. Macroalbuminuric diabetics revealed plasma angiotensin II levels significantly lower than those with microalbuminuria $(p<0.001)$ yet still greater than the normal controls $(p<0.001)$. Of the NIDDM patients, the 30 nephropathic diabetics showed significantly greater angiotensin II plasma levels (28.99 $\pm 5.88 \mathrm{pg} / \mathrm{ml}$ ) than the 15 diabetics without nephropathy $(4.36 \pm 1.49 \mathrm{pg} / \mathrm{ml})(\mathrm{p}<0.001)$ (Table 3$)$.

The serum of the control group of healthy individuals was investigated for ACE activity. The normal values showed a mean of $76.3 \pm 16.5 \mathrm{nmol}$ $/ \mathrm{min} / \mathrm{ml}$. The mean serum ACE activities for the non-complicated, microalbuminuric and macroalbuminuric NIDDM patients were $114.9 \pm 23.3,127.9$ \pm 31.2 and $127.0 \pm 29.3 \mathrm{nmol} / \mathrm{min} / \mathrm{ml}$, respectively. All diabetic groups had significantly greater serum ACE activity $(p<0.001)$ than the controls. No statistical significance was noted in ACE activity on comparing between the diabetic groups (Tables 2 and 3). 
Table 1. Clinical and routine laboratory data of study subjects

\begin{tabular}{|c|c|c|c|c|}
\hline Variable & Control & $\begin{array}{l}\text { Non- } \\
\text { proteinuric } \\
\text { NIDDM }\end{array}$ & $\begin{array}{l}\text { Micro- } \\
\text { albuminuric } \\
\text { NIDDM }\end{array}$ & $\begin{array}{l}\text { Macro- } \\
\text { albuminuric } \\
\text { NIDDM }\end{array}$ \\
\hline $\mathbf{N}$ & 15 & 15 & 15 & 15 \\
\hline Age (years) & $49.6 \pm 6.6$ & $51.3 \pm 6.4$ & $49.4 \pm 4.1$ & $50.8 \pm 5.7$ \\
\hline $\operatorname{Sex}(M / F)$ & $8 / 7$ & $7 / 8$ & $7 / 8$ & $7 / 8$ \\
\hline $\begin{array}{l}\text { Blood pressure } \\
\text { * }_{\text {systolic }} \\
(\mathrm{mmHg}) \\
\text { *diastolic } \\
(\mathrm{mmHg})\end{array}$ & $\begin{array}{c}130 \pm 5 \\
76 \pm 6\end{array}$ & $\begin{array}{c}132 \pm 11 \\
80 \pm 8\end{array}$ & $\begin{array}{c}127 \pm 11 \\
79 \pm 7\end{array}$ & $\begin{array}{l}132 \pm 8 \\
81 \pm 8\end{array}$ \\
\hline $\begin{array}{l}\text { Therapy } \\
*_{\text {oral }} \\
\text { * insulin }^{\text {in }}\end{array}$ & - & $\begin{array}{l}N=15 \\
N=0\end{array}$ & $\begin{array}{l}N=12 \\
N=3\end{array}$ & $\begin{array}{l}N=11 \\
N=4\end{array}$ \\
\hline $\begin{array}{l}\text { Duration of } \\
\text { NIDDM (years) }\end{array}$ & - & $4.3 \pm 1.6$ & $6.8 \pm 4.4$ & $10.5 \pm 2.6$ \\
\hline $\begin{array}{l}\text { Fundus } \\
\text { *normal }^{*} \text { *background } \\
\text { retinopathy }\end{array}$ & - & $\begin{array}{l}\mathrm{N}=15 \\
\mathrm{~N}=0\end{array}$ & $\begin{array}{l}N=8 \\
N=7\end{array}$ & $\begin{array}{l}N=5 \\
N=10\end{array}$ \\
\hline $\begin{array}{l}\text { Peripheral } \\
\text { neuropathy }\end{array}$ & - & $\mathrm{N}=0$ & $\mathrm{~N}=11$ & $\mathrm{~N}=11$ \\
\hline $\begin{array}{l}\text { Fasting glucose } \\
(\mathrm{mg} / \mathrm{dl})\end{array}$ & $\begin{array}{c}82.2 \pm \\
10.3\end{array}$ & $193.0 \pm 49.0$ & $180.2 \pm 63.9$ & $182.7 \pm 59.5$ \\
\hline $\begin{array}{l}\text { Serum } \mathrm{Na} \\
(\mathrm{mEq} / \mathrm{l})\end{array}$ & $\begin{array}{c}138.2 \pm \\
4.0 \\
\end{array}$ & $136.5 \pm 3.7$ & $138.1 \pm 4.8$ & $137.6 \pm 3.9$ \\
\hline Serum K (mEq/l) & $3.9 \pm 0.2$ & $4.0 \pm 0.3$ & $4.1 \pm 0.2$ & $4.1 \pm 0.2$ \\
\hline $\begin{array}{l}\text { Serum urea } \\
(\mathrm{mg} / \mathrm{dl})\end{array}$ & $\begin{array}{c}20.5 \pm \\
3.3 \\
\end{array}$ & $25.8 \pm 7.8$ & $29.5 \pm 11.5$ & $44.5 \pm 18.4$ \\
\hline $\begin{array}{l}\text { Serum creatinine } \\
(\mathrm{mg} / \mathrm{dl})\end{array}$ & $0.9 \pm 0.2$ & $0.9 \pm 0.2$ & $0.9 \pm 0.3$ & $1.4 \pm 0.5$ \\
\hline
\end{tabular}

Data are expressed as means $\pm \mathrm{SD}$.

The upper limit of the normal value of ACE activity, calculated as the mean +2SD, was $109.3 \mathrm{nmol}$ $/ \mathrm{min} / \mathrm{ml}$. Among the NIDDM patients, $53.3 \%$ had serum ACE activity greater than this cut-off value.

ACE activity in NIDDM patients with background retinopathy $(\mathrm{n}=17)$ was $133.1 \pm 28.8 \mathrm{nmol} / \mathrm{min} / \mathrm{ml}$, which was similar to ACE activity in patients with normal fundus $(\mathrm{n}=28,120.1 \pm 30.6 \mathrm{nmol} / \mathrm{min} / \mathrm{ml})$. No significant difference was obtained in serum ACE activity between diabetics on oral hypoglycemic drugs $(n=38)$ and those on insulin therapy $(n=7)$
$(125.2 \pm 30.3$ versus $112.7 \pm 24.6 \mathrm{nmol} / \mathrm{min} / \mathrm{ml}$, respectively).

Linear regression analyses confined to the diabetic subjects (non-complicated, microalbuminuric and macroalbuminuric) were performed in a trial to correlate serum ACE activity (the dependent variable) with duration of diabetes, fasting blood glucose level and blood pressure (both systolic and diastolic) (data not shown). None were significantly related to ACE activity in serum among diabetic patients (correlation coefficient $\mathrm{r}<0.4, \mathrm{p}>0.05$ ). 
Table 2. Specific laboratory data for the renin-angiotensin system in all studied groups.

\begin{tabular}{ccccc}
\hline Variable & Control & $\begin{array}{c}\text { Non- } \\
\text { proteinuric } \\
\text { NIDDM }\end{array}$ & $\begin{array}{c}\text { Micro- } \\
\text { albuminuric } \\
\text { NIDDM }\end{array}$ & $\begin{array}{c}\text { Macro- } \\
\text { albuminuric } \\
\text { NIDDM }\end{array}$ \\
\hline $\mathrm{N}$ & 15 & 15 & 15 & 15 \\
\hline $\begin{array}{c}\text { Plasma renin } \\
\text { activity } \\
\text { (ng/ml/hr) }\end{array}$ & $1.28 \pm 0.37$ & $1.56 \pm 0.82$ & $1.08 \pm 0.48$ & $0.65 \pm 0.10^{\mathrm{abc}}$ \\
\hline $\begin{array}{c}\text { Serum } \\
\text { angiotensin } \\
\text { converting } \\
\text { enzyme activity } \\
(\text { nmol/min/ml) }\end{array}$ & $76.3 \pm 16.5$ & $114.9 \pm 28.3^{\mathrm{a}}$ & $127.9 \pm 31.2^{\mathrm{a}}$ & $127.0 \pm 29.3^{\mathrm{a}}$ \\
\hline $\begin{array}{c}\text { Plasma } \\
\text { angiotensin II } \\
\text { (pg/ml) }\end{array}$ & $14.87 \pm 3.48$ & $4.36 \pm 1.49^{\mathrm{a}}$ & $38.02 \pm 6.92^{\mathrm{ab}}$ & $19.95 \pm 3.60^{\mathrm{abd}}$ \\
\hline
\end{tabular}

Data are expressed as means $\pm \mathrm{SD}$

${ }^{a} \mathrm{p}<0.001$ vs control.

${ }^{b} p<0.001$ vs non-proteinuric NIDDM.

${ }^{c} p<0.05$ vs microalbuminuric NIDDM.

${ }^{d} \mathrm{p}<0.001$ vs microalbuminuric NIDDM.

Table 3. Statistical comparisons for non-insulin dependent diabetics with and without nephropathy

\begin{tabular}{ccc}
\hline Variable & $\begin{array}{c}\text { NIDDM with } \\
\text { nephropathy }\end{array}$ & $\begin{array}{c}\text { NIDDM without } \\
\text { nephropathy }\end{array}$ \\
\hline $\mathrm{n}$ & 30 & 15 \\
\hline $\begin{array}{c}\text { Plasma renin activity } \\
(\mathrm{ng} / \mathrm{ml} / \mathrm{hr})\end{array}$ & $0.87 \pm 0.41$ & $\mathrm{P}<0.01$ \\
\hline $\begin{array}{c}\text { Serum angiotensin } \\
\text { converting enzyme }\end{array}$ & $127.5 \pm 29.8 \quad \mathrm{P}>0.05$ \\
$\begin{array}{c}\text { activity (nmol/min/ml) } \\
\text { NS }\end{array}$ \\
\hline $\begin{array}{c}\text { Plasma angiotensin II } \\
(\mathrm{pg} / \mathrm{ml})\end{array}$ & $28.99 \pm 5.88 \quad \mathrm{P}<0.001$ \\
\hline
\end{tabular}

Data are expressed as means \pm SD

NS $=$ non-significant

\section{Discussion}

Of the several mechanisms regulating renal function in the healthy individual, the renin-angiotensin system, with its potent effects on systemic and local renal hemodynamics and on volume regulation, plays a cardinal role in the regulation of renal function [6]. There have been conflicting reports on the activity of the RAS in diabetes mellitus and numerous abnormalities have been described $[7,8,9]$.

In the present study, hyporeninism was significantly prominent in macroalbuminuric diabetics when compared with control subjects, normoalbuminuric and microalbuminuric diabetic groups.

In addition, a significant negative correlation was obtained between plasma renin activity and serum creatinine levels in the diabetic subjects with macroalbuminuria.

The mechanisms for decreased plasma renin activity have yet to be conclusively clarified, however, various factors may be hypothesized as to how diabetes mellitus negatively affects renin secretion. Since the kidney is the main organ of renin production and secretion, nephropathy results in glomerulo- 


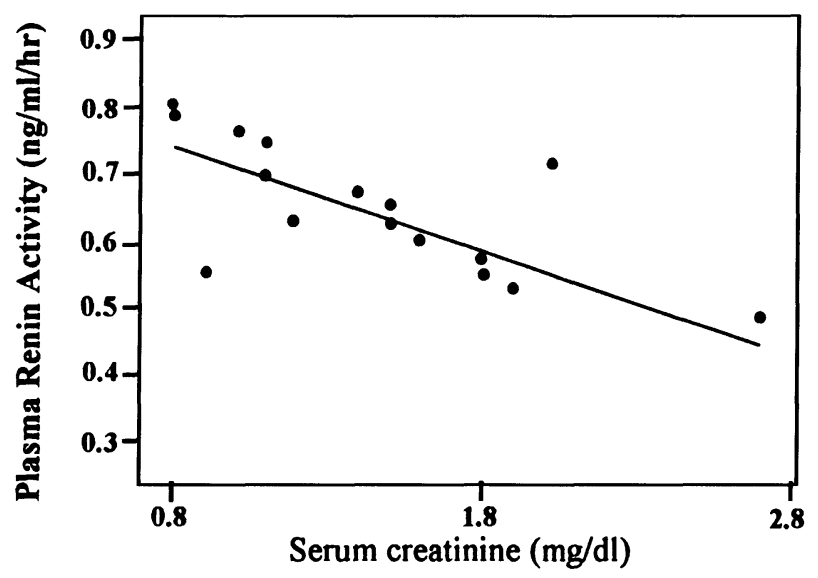

Fig 1. Correlation of plasma renin activity and serum creatinine in NIDDM patients with macroalbuminuria $(\mathrm{r}=-0.842 ; \mathrm{p}<0.001 ; \mathrm{n}=15 ; \mathrm{y}=0.864904-0.154197 \mathrm{x})$.

sclerosis and renal afferent arteriolar hyalinization which alters the juxtaglomerular cells, leading to impaired renin release [10].

Plasma angiotensin II levels were significantly decreased in normoalbuminuric non-insulin dependent diabetics when compared to control subjects. These same patients, however, showed comparatively elevated plasma renin activity (although not significantly so) in comparison with normal controls. Reduced plasma angiotensin II may result from the suppressive effect of renin on angiotensinogen release from the liver which is a precursor of angiotensin I and subsequently angiotensin II [11].

NIDDM patients with nephropathy had significantly greater plasma angiotensin II levels than the non-complicated diabetics denoting diffuse microangiopathy as a part of diabetic vascular complica- tions.

Serum ACE activity in the present study was increased in $53.3 \%$ of the NIDDM patients. Erman et al. [12] and Vandyk et al. [2] found ACE activity to be increased in $35 \%$ and $40 \%$ of their diabetic patients respectively. This discrepancy is attributed to higher serum ACE activity in their control subjects thus clearly raising the cut-off values used in the assessment of increased ACE activity.

Both nephropathic and normoalbuminuric diabetics had significantly greater serum ACE activity than the normal controls, yet no significant difference was obtained between complicated and uncomplicated diabetics. The lack of association between the presence of diabetic nephropathy and raised serum ACE activity is an important argument against the intriguing concept that systemic diabetic microangiopathy leads to an increase in ACE activity. These findings were also confirmed by Schernthaner et al. [13].

In conclusion, our case-controlled cross-sectional study (despite the relatively small number of patients) showed that plasma renin activity initially is insignificantly increased in non-complicated non-insulin dependent diabetic patients and becomes increasingly suppressed with the progression of diabetic nephropathy. Plasma angiotensin II is significantly decreased in normoalbuminuric proteinuric diabetics and elevated in both micro- and macroalbuminuric diabetic patients. Serum ACE activity is significantly raised in NIDDM patients with no correlation between serum ACE activity and albumin excretion rate. However, the precise underlying mechanism for the increased serum ACE activity in non-insulin dependent diabetics remains to be clarified.

\section{References}

1. Damsgaard M, Froland A, Jorgensen D, Morgensen CE (1992) Eight to nine year mortality in known non-insulin dependent diabetics and controls. Kidney Int 41: 731-735.

2. Vandyk D, Erman A, Erman B, Chen-gal B, Sulkes J, Boner G (1994) Increased serum angiotensin converting enzyme activity in type I insulin-dependent diabetes mellitus: its relation to metabolic control and diabetic complications. Eur J Clin Invest 24: 463-467.

3. Kennefick T, Anderson S (1997) Role of angiotensin II in diabetic nephropathy. Seminars in Nephrology
17 (5): 441-447.

4. World Health Organization: WHO Expert Committee on Diabetes Mellitus. Second Report. Geneva, World Health Org., 1980 (Tech. Rep. Ser., no. 646).

5. The DCCT Research Group: Factors in the development of diabetic neuropathy: baseline analysis of neuropathy in feasibility phase of Diabetes Control and Complications Trial. Diabetes 37: 476-481, 1988.

6. Sraer J, Kanfer A, Rondeau E, Lacave R (1989) Role of the renin-angiotensin system in the regulation of glomerular filtration. J Cardiovasc Pharmacol 14 (4): 
21-25.

7. Lieberman J, Sastre A (1980) Serum angiotensinconverting enzyme: elevations in diabetes mellitus. Ann Int Med 93: 825-826.

8. Giampietro O, Lenzi S, Sampietro T, Miccoli R, Navalesi R (1986) Serum angiotensin-converting enzyme in diabetes melitus:a negative report. Enzyme 35: 101-105.

9. O’Donnell M, Lawson N, Barnett AH (1989) Activity of the unstimulated renin-angiotensin-aldosterone system in type I diabetic patients with and without proteinuria. Diabetic Med. 6 (5): 422-425.

10. De Franzo R (1980) Hyperkalemia and hyporeninemic hypoaldosteronism. Kidney Int 17: 118-124.

11. Wolf G, Ziyadeh F (1997) The role of angiotensin II in diabetic nephropathy: emphasis on non haemodynamic mechanism. Am J Kidney Dis 29 (1): 153158.

12. Erman E, Vandyk D, Chen-gal B, Loya N, Boner G, Rosenfeld J (1992) Enhanced angiotensin converting enzyme activity in serum of insulin-dependent diabetic patients: relationship to albuminuria and retinopathy. Isr J Med Sci 28: 764-770.

13. Schernthaner G, Schwarzer C, Kuzmits R, Muller M, Klemen U, Freyler H (1984) Increased angiotensinconverting enzyme activities in diabetes mellitus: analysis of diabetes type, state of metabolic control and occurrence of diabetic vascular disease. J Clin Pathol 37: 307-312. 